\title{
The Presence of Fimbriae (Pili) in Three Species of Neisseria
}

\author{
By G. A. WISTREICH AND R. F. BAKER \\ Department of Microbiology, School of Medicine, \\ University of Southern California, Los Angeles, California 90033, U.S.A.
}

(Accepted for publication 7 December 1970)

\section{SUMMARY}

Fimbriae (pili) were demonstrated in three of four Neisseria species (Neisseria catarrhalis, N. perflava, N. subflava) by electron microscopy. Only one of three $N$. catarrhalis strains examined exhibited these non-flagellar appendages. Haemagglutination occurred with all strains bearing such surface structures, but different species reacted in different ways. Neisseria catarrhalis and $N$. perflava agglutinated mouse and rabbit red cells at 0 and $37^{\circ} ; N$. subflava reacted similarly only with rabbit erythrocytes, and with human $\mathrm{O}$ cells at $0^{\circ}$. No reactions were observed with guinea pig, goat or sheep red cells. Prior heating of the organisms destroyed all obvious haemagglutination activity; addition of $\mathrm{D}$-mannose did not inhibit haemagglutination.

\section{INTRODUCTION}

Bacterial fimbriae, or pili, are described as filamentous surface appendages having various diameters and lengths. Their presence on bacterial cells can be detected directly by standard electron microscopy procedures, e.g. negative staining and shadowcasting, and indirectly by haemagglutination (HA) tests. Haemagglutination alone, however, is not a reliable indicator of the presence of fimbriae as it can be caused by other means in their absence, i.e. 'non-fimbrial haemagglutination' (Duguid, Smith, Dempster \& Edmunds, I955; Duguid, Anderson \& Campbell, I966). Moreover, certain fimbriated bacteria have been reported not to produce the HA reaction (Duguid \& Gillis, I958; Cruickshank, 1965).

Fimbriae (pili) are differentiated from flagella on the basis of their smaller diameter, the absence of the sinuous shape characteristic of flagella and lack of an association with motility. Early studies of fimbriation (Duguid \& Gillies, I957, 1958; Brinton, 1959; Thornley \& Horne, 1962; Brinton, 1965) established these characteristics, and demonstrated the presence of fimbriae in a large number of genera in the Enterobacteriaceae. More recent studies have shown that genera belonging to other families also possess fimbriae. Examples are species of Pseudomonas (Fuerst \& Hayward, 1969), Vibrio (Tweedy, Park \& Hodgkiss, 1968) and Herellea (Swanson \& Goldschneider, I969). Fimbriae are apparently not limited to Gram-negative bacteria, since they have reported for variants of group A streptococci (Swanson \& McCarty, 1969) and numerous strains of Corynebacterium renale (Yanagawa \& Otsuki, I970). The findings of the former investigation, however, should not be considered conclusive, because standard procedures for the characterization of fimbriae were not used.

As far as we know, this is the first report of fimbriae (pili) in the genus Neisseria. 
We were able to study bacterial haemagglutination with the scanning electron microscope, which proved to be of great value in exploring the spatial relationship between fimbriae and erythrocytes.

Throughout this report we use the term 'fimbriae' rather than 'pili' since we contend that the former term not only has priority, but that its meaning has been clearly expressed by Duguid et al. (I955). Like Fuerst \& Hayward (1969) we agree with the views presented by Duguid (1966) and Duguid \& Anderson (1967) in support of the use of the term 'fimbriae'.

\section{METHODS}

Organisms. Of the nine bacterial species used, Neisseria catarrhalis, N. perflava, Proteus mirabilis, Mima polymorpha and Vibrio metschnikovii came from the stock culture collection of the Bacteriology Section, Division of Biological Sciences, University of Southern California, Los Angeles. The remaining four species, $N$. catarrhalis (ATCC8I76, ATCC8I93), N. flava (ATCC 1422I), and N. subflava (ATCC 19243) were from the American Type Culture Collection, Rockville, Maryland. Biochemical tests were made to confirm the identity of all Neisseria strains. Mima polymorpha, $N$. catarrhalis (ATCC8193), P. mirabilis, and V. metschnikovii were used for purposes of comparing haemagglutination reactions of fimbriate bacteria with non-fimbriate ones. Electron microscope examinations of these bacterial species showed fimbriae only on $P$. mirabilis.

Culture methods. All organisms were cultured on tryptic soy agar slants and in tryptic soy broth (Difco Laboratories, Detroit, Michigan) at $28^{\circ}$ for $48 \mathrm{~h}$.

Haemagglutination tests. Bacterial haemagglutination, and its sensitivity to mannose, was studied with red blood cells from six animal species: goat, guinea pig, human $\left(\mathrm{O}, \mathrm{RH}_{0}+\right)$, two strains of mice (Swiss albino, $\left.\mathrm{C}_{3} \mathrm{H} / \mathrm{HeJ}\right)$, rabbit and sheep. Red cells were prepared as described by Cruickshank (1965). Bacteria were grown on solid media for $48 \mathrm{~h}$. at $28^{\circ}$, washed off with sterile saline $(0.9 \%)$ and centrifuged. Pellets were twice washed with sterile saline, resuspended in saline, and refrigerated until needed.

The haemagglutination procedure was similar to that of Tweedy et al. (1968), except that tests were done in duplicate in $10 \times 75 \mathrm{~mm}$. glass tubes, and incubated for I h., one set at $37^{\circ}$ and the other at $4^{\circ}$.

Experiments were made to ascertain the effect of heat on fimbriate bacteria before testing their haemaglutinating activity. The bacteria were harvested, washed once with sterile distilled water and suspended in sterile distilled water. After I h. at $85^{\circ}$, the suspension was cooled, centrifuged, and the bacteria suspended in sterile saline. Haemagglutination only of human $\left(\mathrm{O}, \mathrm{Rh}_{0}+\right)$, and mouse (strain $\left.\mathrm{C}_{3} \mathrm{H} / \mathrm{HeJ}\right)$ red cells was looked for in heated and control (unheated) suspensions. Mannose sensitivity tests were done by adding D-mannose (final concn. $0.7 \%$, w/v) to the reaction mixture.

The ability of fimbriated Neisseria catarrhalis, N. perflava, N. subflava and Proteus mirabilis to adhere to red cell ghosts was also investigated. Ghosts were prepared by adding $2 \mathrm{ml}$. whole blood to ro ml. sterile distilled water, centrifuging, and washing the deposit in sterile physiological saline. The washed ghosts were suspended in $5 \mathrm{ml}$. saline and used as described for haemagglutination.

Electron microscopy. Bacteria from cultures on solid media were harvested and fixed with $0.25 \%$ formaldehyde. With liquid cultures, the bacteria were first centri- 
fuged and then treated with $0.25 \%$ formaldehyde. Preparations were washed twice with sterile distilled water before examination. Specimens were placed on I \% collodion-coated copper grids (200 mesh), and excess fluid removed with filter paper. The grids were allowed to dry and then shadowed with either gold/palladium, or platinum/ palladium alloys. Triplicate specimens were always prepared. A RCA EMU-3 F electron microscope (Radio Corporation of America, Camden, New Jersey) operated at an accelerating voltage of $100 \mathrm{kV}$, and a Philips 300 microscope (Philips Electronic and Pharmaceutical Industries Corporation, Mt Vernon, New York) operated at $80 \mathrm{kV}$ were used.

For negative staining, the bacteria were fixed in formaldehyde suspended in distilled water and mixed with equal volumes of a $I \%(w / v)$ phosphotungstic acid (PTA), $\mathrm{pH} 6 \cdot 8$. Usually $0.3 \%(\mathrm{w} / \mathrm{v})$ sucrose was added to the PTA to enhance its spreading and staining effectiveness.

Scanning electron microscopy. Equal volumes of $2 \%(\mathrm{w} / \mathrm{v})$ glutaraldehyde in phosphate buffer (Cokelet \& Meiselman, 1968), $\mathrm{pH} 7 \cdot 4$, were added to tubes in which haemagglutination was observed. The red cells were collected by centrifugation (2000 rev./min. for $10 \mathrm{~min}$.), washed twice in sterile distilled water and suspended in $2 \mathrm{ml}$. phosphate buffer. Samples were placed on polished flat surfaces of circular aluminium specimen stubs and mixed with one or two drops of a $I: 600$ dilution of PhotoFlo 200 solution (Eastman Kodak Company, Rochester, New York) to facilitate spreading. After drying at $60^{\circ}$, the specimens were fastened to a turntable (Cone Shadowing Accessory, Edwards High Vacuum Ltd, Manor Royal, Crawley, Sussex), coated with a thin film of carbon and then shadowed with gold, $200 \AA$ thick. A Cambridge Steroscan electron microscope, Mark II (Cambridge Instrument Co. Ltd, London) was used with an accelerating voltage of $20 \mathrm{kV}$ and a specimen angle of $5 \mathrm{I}^{\circ}$. Photographs were made with a Polariod sheet film, Type 55 P/N (Polaroid Corporation, Cambridge, Massachusetts).

\section{RESULTS}

\section{Electron microscopy}

The presence of fimbriae was observed in one of the three strains of Neisseria catarrhalis, in N. perflava and in N. subflava ATCC 19243 (Pl. I, fig. I, 2, 3; Pl. 2, fig. 4, $5)$. Measurements of length were made from prints of negatives of shadowed cells, but only from those structures which were perpendicular to the line of shadowing. Photographs of phosphotungstic acid-stained cells were used in the case of $N$. catarrhalis.

The majority of the organisms in both shadowed and negatively stained preparations were found to bear fimbriae. The number of fimbriae per cell varied considerably; some cells had as few as 25 , others had 60 to Ioo. Determining the actual count was often difficult as many surface structures formed bundles. Furthermore, although the organisms were fixed before examination, whole fimbriae, as well as smaller fragments, apparently became detached since filaments were seen scattered over the background of shadowed specimens. Individual fimbriae exhibited slight curvatures and tapering along their lengths. Autolysed cells retained fimbriae.

The arrangements and dimensions of the fimbriae differed among the Neisseria species. Cells of Neisseria catarrhalis exhibited a 'peri-fimbriae' pattern (Pl. I, fig. I). Although intercellular connexions were observed with all three species of Neisseria, 
$N$. catarrhalis showed a far greater number of them (Pl. I, fig. 2). Based on measurements of length, two fimbriae types were seen which differed in their distribution. Several cells had numerous short filaments emerging from their outer borders, with an occasional long filament extending beyond them. In other organisms the longer type predominated. The diameters of both appendages ranged from 4.0 to $4.5 \mathrm{~nm}$. The lengths of the shorter structures measured 0.5 to $0.73 \mu \mathrm{m}$., while the longer filaments were $\mathrm{I} 2.5$ to $\mathrm{I} 4 . \mathrm{I} \mu \mathrm{m}$. long (Pl. I, fig. 3). As these cultures were not synchronous, it is possible that both types of appendages were of a similar nature, differing only in their particular stage of development.

With Neisseria perflava, the distribution of surface appendages did not vary to the extent described for $N$. catarrhalis. In general, most cells showed both short and long fimbriae. The former exhibited diameters of 2 to $3 \mathrm{~nm}$. and lengths of about $7 \mu \mathrm{m}$. The longer filaments differed from those of $N$. catarrhalis and $N$. subflava by showing a branching effect near the distal ends (P1. 2, fig. 4); this may have been due to an unravelling of fimbriae bundles, or to the effect of drying specimen preparation.

The fimbriae of Neisseria subflava appeared to be of two types. The predominant form was a short type, 0.2 to $0.3 \mu \mathrm{m}$. long and $6 \mathrm{~nm}$. in diameter, whilst the long type was 2.3 to $3.4 \mu \mathrm{m}$. in length and $6 \mathrm{~nm}$. in diameter.

Selected cultural characteristics of Neisseria species bearing fimbriae. The results of a comparative study of the degree of fimbriation exhibited by agar and broth cultures were in keeping with the observations of other investigators (Duguid \& Gillies, I958; Duguid, 1959). We found that organisms grown on agar media showed fewer fimbriae than those from liquid media. Furthermore, bacteria from subsequent agar subcultures showed a decrease in numbers of fimbriae. Preliminary results of studies involving the cultivation of $N$. catarrhalis at $37^{\circ}$ in both types of media showed that this temperature also decreased the number of fimbriae. A similar observation was noted by Duguid (I959) with respect to certain strains of Klebsiella.

Table I. Haemagglutinating activities of live fimbriated Neisseria species and control micro-organisms

\begin{tabular}{|c|c|c|c|c|c|c|c|c|c|}
\hline \multirow[b]{3}{*}{ Micro-organism } & \multirow{3}{*}{$\begin{array}{l}\text { Fim- } \\
\text { briae }\end{array}$} & \multicolumn{8}{|c|}{ Systems* } \\
\hline & & \multicolumn{2}{|c|}{ Mouse } & \multicolumn{2}{|c|}{ Human } & \multicolumn{2}{|c|}{ Guinea-pig } & \multicolumn{2}{|c|}{ Rabbit } \\
\hline & & $0^{\circ}$ & $37^{\circ}$ & $0^{\circ}$ & $37^{\circ}$ & $0^{\circ}$ & $37^{\circ}$ & $0^{\circ}$ & $37^{\circ}$ \\
\hline Mima polymorpha & - & - & - & - & - & n.t. & n.t. & n.t. & n.t. \\
\hline Neisseria catarrhalis & + & + & + & - & - & - & - & + & + \\
\hline $\begin{array}{l}\text { N. catarrhalis ATCC } \\
8193\end{array}$ & - & - & - & - & - & n.t. & n.t. & n.t. & n.t. \\
\hline$N$. perflava & + & + & + & - & - & - & - & + & + \\
\hline $\begin{array}{l}\text { N. subflava ATCC } \\
\text { I } 9423\end{array}$ & + & - & - & + & - & - & - & + & + \\
\hline Proteus mirabilis & + & - & - & - & - & + & + & - & - \\
\hline Vibrio metschnikovii & - & $(+)$ & $(+)$ & - & - & + & - & + & - \\
\hline
\end{tabular}

\section{Haemagglutination tests}

The reactions produced by preparations containing live Mima polymorpha, Neisseria catarrhalis, $N$. catarrhalis ATCC8193, N. perflava, $N$. subflava ATCC 19243, Proteus 
mirabilis and Vibrio metschnikovii are shown in Table I. Because no Neisseria species or control organisms agglutinated goat or sheep red cells, these results were not included in the table. No auto-agglutination was observed in the controls, which contained red cells alone and saline.

Both Neisseria catarrhalis and $N$. perflava agglutinated only red cells from rabbit and the two mouse strains used. Neisseria subflava, on the other hand, agglutinated only rabbit and human red cells. Thus these species can be differentiated according to their haemagglutinating activities. With respect to control organisms, only Proteus mirabilis and Vibrio metschnikovii produced reactions. Proteus mirabilis agglutinated mouse red cells at both o and $37^{\circ}$. Vibrio metschnikovii reacted strongly with rabbit red cells at $0^{\circ}$ but not at $37^{\circ}$ and only with mouse cells at $o$ and $37^{\circ}$. The latter reaction was characterized by extremely small granular formations.

Although prior heat treatment eliminated all haemagglutinating activity, D-mannose (final concentration $0.7 \%$, w/v) had no effect on any of the fimbriated Neisseria species tested.

Scanning electron microscope examination of systems showing haemagglutination revealed the pronounced adhesive property of both bacterial cells and their fimbriae to erythrocytes (Pl. 2, fig. 6). Fimbriae were also observed to adhere to one another. Examinations of specimens by transmission electron microscopy did not present so true a representation of spatial relationships between bacteria, fimbriae and red cells. The means of attachment was not as evident as in the scanning micrographs. To demonstrate the attachment of fimbriae to red cells, agglutinated erythrocytes were lysed in situ, fixed overnight in $2 \%(\mathrm{v} / \mathrm{v})$ glutaraldehyde and negatively stained. Although these preparations showed the adherence of bacteria to red cells, they did not yield any additional information. The reactions of Proteus mirabilis were also examined by scanning and by transmission electron microscopy. These organisms also adhered to red cells; however, from scanning electron micrographs it appeared that erythrocytes were stuck to the surfaces of large accumulations of bacteria (Pl. 2, fig. 7). Fimbriae were not obvious in such preparations even though they could be seen in pure specimens of the organism.

Agglutinated ghosts of mouse and human red cells examined by electron microscopy clearly showed the adherence of bacteria to them. However, fimbriae were either not seen or were observed only with great difficulty.

\section{DISCUSSION}

Our electron microscope examinations have shown the existence of fimbriae in three Neisseria species, which resemble in several respects the surface appendages of other bacteria. These structures of Neisseria catarrhalis, N. perflava and N. subflava exhibited diameters and lengths which, for the most part, were within the range of measurements used by Brinton (1965) and Duguid et al. (1966) in their respective characterizations of pili and fimbriae. Specifically, the appendages of $N$. catarrhalis appear to be similar to the type 4 fimbriae, while the longer structures resemble the type 6 fimbriae described by Duguid et al. (1966). With respect to the former category, $N$. catarrhalis appendages showed approximately the same diameters, exhibited mannose resistance and were capable of reacting with untreated erythrocytes. Similarity to the type 6 structures was based on the unusual lengths of the fimbriae observed, the 
relative low numbers of these appendages and the display of the 'weak' mannose sensitivity (MS) reactions in haemagglutination tests. We interpret the latter property to mean mannose insensitivity. One feature of the type 6 fimbriae does, however, present a problem, since the diameter of the structures observed by Duguid (Duguid et al. I966) was exceptionally large (about Io $\mathrm{nm}$.). If each of these fimbriae was in fact composed not of just one fibril but of a bundle of such structures, then it is conceivable that their individual diameters would be the same as those of $N$. catarrhalis. Clarification of this point would be helpful in the characterization of the fimbriae of $N$. catarrhalis. Although values for length were not given by Duguid et al. (I966) for type 4 fimbriae, the surface structures of $N$. perflava and $N$. subflava resemble these appendages more than any of the others described by Duguid et al. (1966).

Any discussion of the occurrence of fibriation among different bacterial species, as emphasized by Fuerst \& Hayward (1969), requires an interpretation of negative findings. The absence of fimbriae on cells from cultures of Neisseria catarrhalis (ATCC 8I76, ATCC8193) and N. flava (ATCC I422I) may be attributable to any one, or a combination of the factors listed by Fuerst \& Hayward (1969): these include genetic incapability to form fimbriae, inhibitory effects of the cultural conditions used, and the phase of development at the time sampling was made. It would appear that additional studies using a variety of culture conditions and other strains of these bacteria are warranted to confirm our findings.

The Neisseria species bearing fimbriae showed haemagglutinating activities which differed in some respects from, and yet in other ways resembled, the reactions described for the fimbriated organisms in the family Enterobacteriaceae. The finding that haemagglutination occurred with washed organisms suggested that the bacteria themselves and/or their fimbriae were responsible for the phenomenon, and not a diffusible haemagglutinin. Confirmation of this point was provided with the aid of the scanning electron microscope. This instrument clearly showed the adherent and cohesive nature of Neisseria fimbriae. The latter property was of particular advantage in detecting the surface appendages as they tended to form aggregates or bundles. A similar situation was not observed with the highly fimbriated Proteus mirabilis.

The authors thank Dr James W. Bartholomew for his helpful suggestions, Mr Rupert Perrin (Calbiochem, Los Angeles, California) for the supply of citrated red cell preparations, Mr John Devaney (Jet Propulsion Laboratories, Pasadena, California) for the scanning microscopy, Dr C. G. Loosli for access to his Philips 300 microscope, and Dr I. Sultanian for the $\mathrm{C}_{3} \mathrm{H} / \mathrm{HeJ}$ mice.

This investigation was supported by the National Institutes of Health training grant AI 157-10, and the National Heart Institute, U.S. Public Health Service grant HE 07976-07.

\section{REFERENCES}

Brinton, C. C. JuN. (1959). Non-flagellar appendages of bacteria. Nature, London 183, 782-786. Brinton, C. C. JuN. (1965). The structure, function, synthesis and genetic control of bacterial pili and a molecular model for DNA and RNA transport in Gram-negative bacteria. Transactions of the New York Academy of Sciences 27, 1003-1054.

Cokelet, G. R. \& Meiselman, H. J. (1968). Rheological comparison of hemoglobin solution and erythrocyte suspensions. Science, New York 192, 275-277.

Cruickshank, R. (1965). Medical Microbiology. Baltimore: The Williams and Wilkins Company. 


Journal of General Microbiology, Vol. 65, No. 2

Plate 2
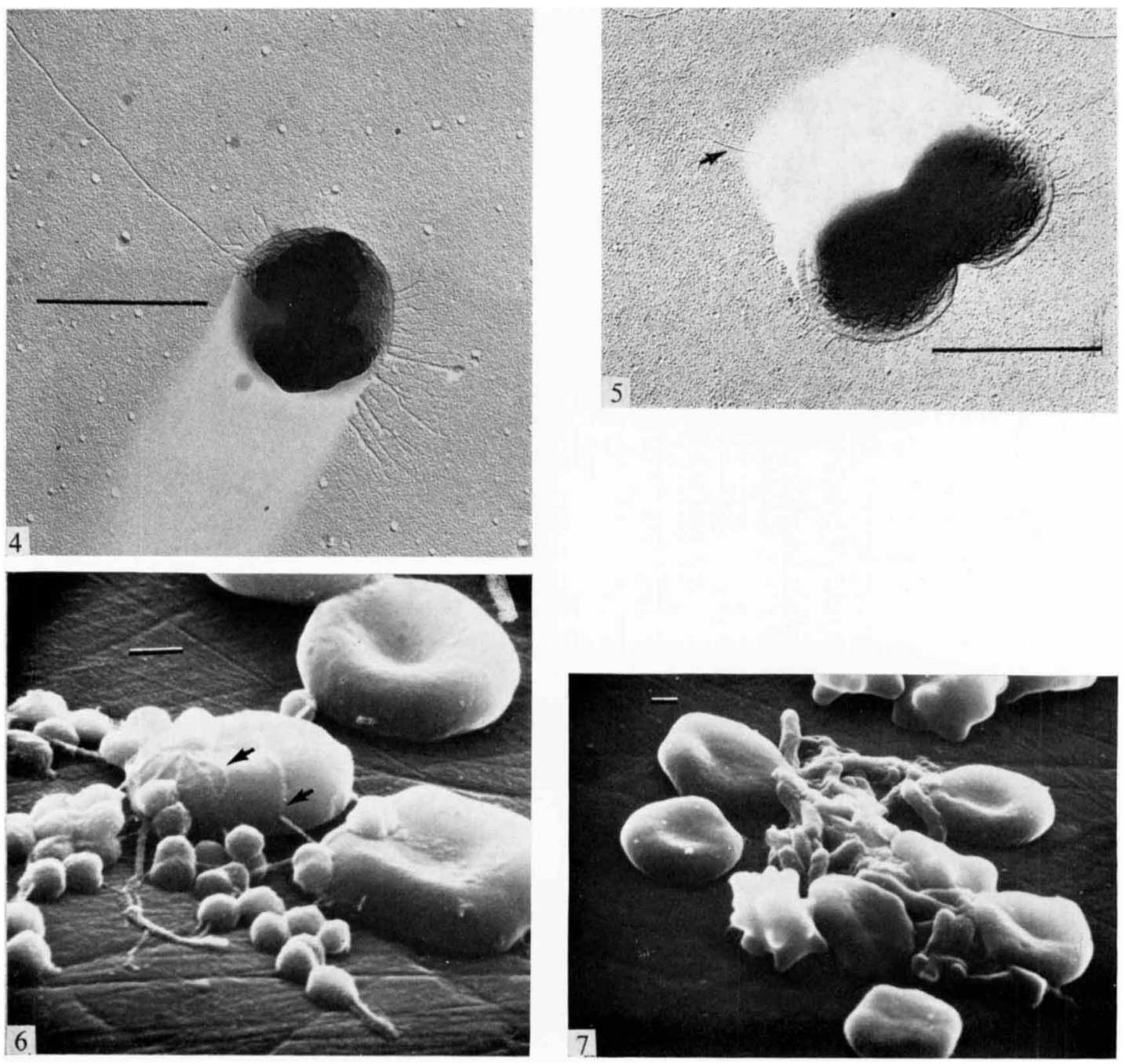

G. A. WISTREICH AND R. F. BAKER 
Dugund, J.P. (1959). Fimbriae and adhesive properties of Klebsiella strains. Journal of General Microbiology 21, 271-286.

Dugum, J. P. (1966). Note on the terms 'fimbriae' and 'pili'. Journal of Pathology and Bacteriology 92, I37-I 38.

DUGUID, J. P. \& ANDERSON, E. S. (1967). Terminology of bacterial fimbriae, or pili and their types. Nature, London 215, 89-90.

Duguid, J. P., ANDERSon, E. S. \& CAMPBell, I. (1966). Fimbriae and adhesive properties in Salmonella. Journal of Pathology and Bacteriology 92, 107-1 37.

Duguid, J. P. \& GILIES, R. R. (1957). Fimbriae and adhesive properties in dysentery bacilli. Journal of Pathology and Bacteriology 74, 397-41 I.

Duguid, J. P. \& Gillies, R. R. (I958). Fimbriae and hemagglutinating activity in Salmonella, Klebsiella, Proteus and Chromobacterium. Journal of Pathology and Bacteriology 75, 519-520.

Duguid, J. P., Smith, I. W., Dempster, G. \& Edmunds, P. N. (I955). Non-flagellar filamentous appendages ('fimbriae') and haemagglutinating activity in Bacterium coli. Journal of Pathology and Bacteriology 70, 335-348.

FUERST, J. A. \& HAYWARD, A. C. (1969). Surface appendages similar to fimbriae.(pili) on Pseudomonas species. Journal of General Microbiology 58, 227-237.

Swanson, J. \& GolDSCHNEIDER, I. (1969). The serum bactericidal system: ultrastructural changes in Neisseria meningitidis exposed to normal rat serum. Journal of Experimental Medicine 129, 5I-80.

SwANSON, J. \& MCCARTY, M. (1969). Electron microscopic studies on opaque colony variants of group A streptococci. Journal of Bacteriology 100, 505-51 1.

THORNLEY, M. J. \& HoRNE, R. W. (I962). Electron microscope observations on the structure of fimbriae, with particular reference to Klebsiella strains, in the use of the negative staining technique. Journal of General Microbiology 28, 5I-56.

Tweedy, J. M., Park, R. W. A. \& Hodgkiss, W. (I968). Evidence for the presence of fimbriae (pili) on Vibrio species. Journal of General Microbiology 5I, 235-244.

YANAGAWA, R. \& OTSUKI, K. (1970). Some properties of the pili of Corynebacterium renale. Journal of Bacteriology Ior, 1063-1069.

\section{EXPLANATION OF PLATES}

The bar marker in all photographs represents $\mathrm{I} \mu \mathrm{m}$.

\section{Plate I}

Fig. I. Neisseria catarrhalis stained with phosphotungstic acid. Numerous fimbriae are visible. $\times 41,000$.

Fig. 2. A gold/palladium shadowed preparation of $N$. catarrhalis from a $48 \mathrm{~h}$. broth culture. Several intercellular connexions are apparent. $\times 45,700$.

Fig. 3. A platinum/palladium (Pt/Pd) shadowed specimen of $N$. catarrhalis with long fimbriae (arrows). Note the thickened basal portion of the structure, as well as the tapering effect. $\times 10,000$.

\section{Plate 2}

Fig. 4. Neisseria perflava, a Pt/Pd shadowed cell exhibiting branching fimbriae. Both short and long filaments are shown. $\times 32,000$.

Fig. 5. N. subflava ATCC19243, shadowed with Pt/Pd. The predominance of short fimbriae are evident. One long appendage (arrow) can be seen emerging from the shadow region. $\times 32,000$.

Fig. 6. A scanning micrograph of the cells of $N$. catarrhalis, and their fimbriae causing the agglutination of mouse red cells. The adhesive nature of the fimbriae (arrows) can be seen. $\times 10,000$.

Fig. 7. A scanning micrograph of Proteus mirabilis agglutinating red blood cells. The adherence of red cells to aggregates of bacteria can be seen. $\times 5000$. 